\title{
Framework Peningkatan Kualitas Informasi Melalui Perbaikan Proses Produksi Informasi
}

\author{
Fathonah Tri Hastuti ${ }^{1}$, Albarda ${ }^{2}$ \\ ${ }^{I}$ Badan Pusat Statistik, Jl.Purbaya, Sumberadi, Mlati, Sleman, Yogyakarta, 55288, Indonesia \\ ${ }^{1}$ fathonah@bps.go.id, ${ }^{2}$ albar@stei.itb.ac.id
}

\section{INFORMASI ARTIKEL}

\section{Sejarah Artikel:}

Diterima Redaksi: 30 Januari 2020

Revisi Akhir: 13 Maret 2020

Diterbitkan Online: 18 Maret 2020

\section{KATA KUNCI}

Kualitas Informasi,

Alur Informasi,

Peningkatan Kualitas Informasi,

Dimensi Kualitas Informasi,

Kematangan

KORESPONDENSI

Telepon: 081905598867

E-mail: fathonah@bps.go.id

\section{A B $\mathbf{S}$ T $\mathbf{R}$ A $\mathbf{C}$ T}

A Government requires a mapping its country to make the development more precisely targeted and evenly. Government agencies that the function is to perform the data collection in this country is the Statistics of Indonesia (BPS). To answer the complex problems faced by the government or private, BPS is expected to improve the quality of information produced. To improve the quality of information, the necessary framework that can be used as a guide in measuring and improving the quality of information is needed. The proposed framework in this research was carried out based on study literature. The quality of information was assessed during the information production process. The information production process was improved based on the maturity and attributes concept in COBIT 4.1. The main purpose of this research is to design a framework that can guide to improve the quality of the information in the form of recommendations for information production improvement.

\section{PENDAHULUAN}

Saat ini informasi sudah menjadi kebutuhan seharihari bagi semua kalangan, baik bagi pribadi, komunitas, masyarakat, swasta maupun pemerintah. Perusahaan membutuhkan informasi untuk mendukung kelangsungan perkembangan perusahaan. Pemerintah membutuhkan informasi sebagai bahan evaluasi pembangunan yang telah dilakukan dan juga sebagai dasar perencanaan pembangunan. Perencanaan yang dilakukan tanpa didasari data yang akurat dapat berakibat pembangunan yang tidak tepat sasaran, dan memicu permasalahan-permasalahan yang lain. Secara umum dapat dikatakan bahwa masalah informasi mempunyai efek yang beruntun, mahal dan bahkan bisa menjadi bencana.

Informasi mengenai kondisi negara secara menyeluruh, baik itu kondisi ekonomi, kesehatan, pendidikan, kependudukan, pertanian, dan lainnya, sangat diperlukan oleh pemerintah. Artinya, pemerintah membutuhkan pemetaan kondisi negaranya. Pemetaan kondisi negara sangat dibutuhkan sebagai bahan pengambilan keputusan agar pembangunan yang dilakukan dapat tepat sasaran dan merata.

Ketersediaan data tentang kondisi negara hanya bisa didapat melalui proses pengumpulan data. Lembaga pemerintah yang berfungsi untuk melakukan pengumpulan data di negara ini adalah Badan Pusat Statistik (BPS). Saat ini, permasalahan yang harus diselesaikan baik oleh pemerintah maupun swasta semakin kompleks. Selain itu, muncul berbagai pendapat baik pro maupun kontra terhadap kualitas data BPS. Hal tersebut merupakan indikasi bahwa kualitas data BPS masih perlu ditingkatkan dan merupakan tantangan tersendiri bagi BPS untuk melakukan perubahan dan inovasi.

Salah satu unsur penting dalam modernisasi dan inovasi BPS adalah peningkatan penggunaan infrastruktur 
teknologi dan komunikasi (TIK). Peran TIK sangat penting dalam mendukung peningkatan kualitas data yang dikumpulkan oleh BPS. Salah satu bentuk pemanfaatan TIK dalam pengumpulan data adalah dengan menggunakan teknik wawancara dengan teknologi komputer atau disebut dengan istilah CAPI (Computer Assisted Personal Interviewing). Tujuan dari penggunaan CAPI ini adalah agar dalam perekaman, pengumpulan dan pengolahan data lebih cepat dan diharapkan lebih akurat karena data terkoreksi langsung di lapangan pada saat itu juga.

Dalam ilmu manajemen, terdapat ungkapan yang berbunyi "you can't manage what you can't measures", ungkapan tersebut dapat dimaknai bahwa untuk dapat mengelola kualitas informasi yang dihasilkan, maka organisasi perlu melakukan pengukuran terhadap kualitas informasi yang dihasilkan. Pengukuran yang dilakukan selain dapat memberikan gambaran kondisi saat ini, juga dapat dijadikan tolak ukur dalam melakukan perbaikan kualitas informasi.

Untuk mengetahui pendapat pengguna data BPS terhadap data yang dihasilkan, BPS melakukan Survei Kebutuhan Data (SKD). Berdasarkan hasil SKD Tahun 2014 diperoleh informasi bahwa secara nasional, tingkat kepuasan pengguna data terhadap kualitas data sebesar 80,11 persen. Dilihat dari kelompok data yang dicari, sebagian besar pengguna data mencari data pada kelompok data sosial yaitu sebesar 30,47 persen. Hal ini menunjukkan bahwa data sosial memiliki peranan yang penting bagi performansi BPS. Berdasarkan hasil SKD juga dapat diperoleh informasi bahwa di wilayah PST BPS, sebagian pengguna data menganggap bahwa data yang dicari tidak sesuai. Ketidaksesuaian ini terkait dengan kebutuhan pengguna yang semakin tinggi terkait periode, level ataupun jenis data. Persentase pengguna yang menganggap data yang dicari tidak sesuai, dari tahun ke tahun mengalami peningkatan, seperti terlihat pada Gambar 1 .

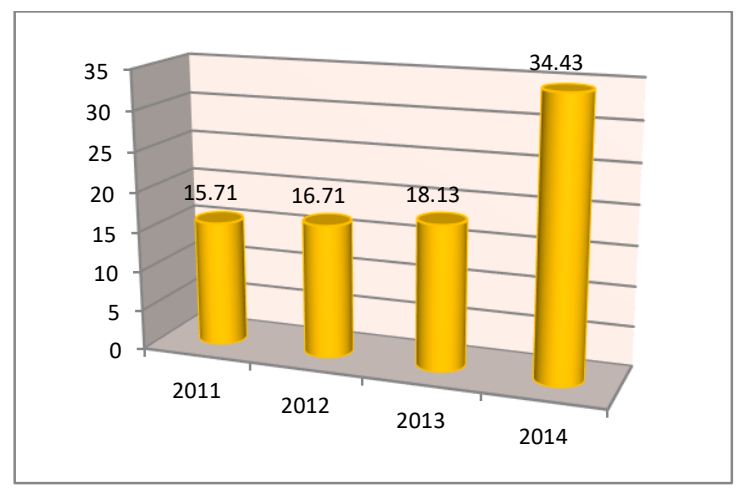

Gambar 1. Persentase data yang tidak sesuai

Peningkatan kebutuhan konsumen akan data yang dihasilkan oleh BPS ini merupakan bukti bahwa data yang dibutuhkan masyarakat semakin berkembang dan kompleks, hal ini juga merupakan sinyal kuat bagi BPS untuk selalu melakukan peningkatan kualitas informasi yang dihasilkan. Hal tersebut juga sejalan dengan tujuan pertama dalam rencana strategis BPS yang akan dilakukan oleh BPS dalam periode 2015-2019.

Penelitian kualitas informasi yang dilakukan oleh BPS ini bersifat subjektif karena diukur dari sudut pandang pengguna data. Pengukuran kualitas informasi ini tidak dapat memberikan langkah yang tepat untuk meningkatkan kualitas informasi yang dihasilkan, padahal tujuan utama organisasi melakukan penelitian adalah untuk dapat menentukan langkah peningkatan yang paling tepat agar menghasilkan produk dengan kualitas yang lebih baik. Metode penilaian kualitas informasi dapat dilakukan terhadap kualitas raw data, informasi, dan sistem produksinya sesuai dengan klasifikasi kriteria informasi yang telah dilakukan oleh Naumann and Rolker (2000) menjadi 3 kriteria: subjek, objek, proses.

Untuk melengkapi penelitian kualitas informasi dari sudut pandang pengguna, dapat dilakukan pengukuran kualitas informasi berdasarkan proses menghasilkan informasi. Pengukuran melalui pendekatan proses lebih dapat memberikan gambaran langkah peningkatan yang dapat diambil organisasi untuk meningkatkan kualitas informasi yang dihasilkan. Informasi yang berkualitas hanya dapat dihasilkan dengan melakukan kontrol secara disiplin terhadap rangkaian proses menghasilkan informasi. Abdullahi Sherif dkk menyatakan bahwa manajemen informasi merupakan salah satu faktor pendorong dalam peningkatan proses menghasilkan informasi.

Dari uraian di atas dapat dikatakan bahwa peningkatan kualitas informasi dapat dilakukan dengan melakukan kontrol terhadap proses menghasilkan informasi. Untuk melakukan peningkatan, pertama diperlukan framework yang dapat digunakan sebagai panduan dalam melakukan pengukuran dan peningkatan kualitas informasi.

\section{LITERATURE REVIEW}

Penelitian yang membahas tentang kualitas informasi sudah banyak dilakukan, seperti ditunjukkan pada Tabel 1 . Secara garis besar, penelitian-penelitian sebelumnya membahas mengenai kualitas informasi dan manajemen informasi secara terpisah. Penelitian tentang kualitas informasi yang sampai sekarang banyak dijadikan referensi adalah penelitian yang dilakukan oleh Wang dkk. yang membahas mengenai dimensi kualitas informasi.

TABel 1. Penelitian yang PeRnah Dilakukan

\begin{tabular}{|l|l|l|}
\hline $\begin{array}{l}\text { Penelitian tentang } \\
\text { Kualitas Informasi }\end{array}$ & \multicolumn{1}{|c|}{ Topik } & \multicolumn{1}{|c|}{ Keterangan } \\
\hline $\begin{array}{l}\text { Beyond Accuracy: } \\
\text { What Data Quality }\end{array}$ & $\begin{array}{l}\text { Dimensi } \\
\text { kualitas data/ } \\
\text { informasi }\end{array}$ & $\begin{array}{l}\text { Mengklasifikasikan Data } \\
\text { dimensi kualitas data }\end{array}$ \\
Customer, Wang & & \\
dan Strong & & Membahas tentang \\
Identifying & Atribut & hubungan antar atribut \\
Relationships of & dimensi & dimensi yang dapat saling \\
Information Quality & kualitas & \\
Dimensions, Sang & informasi & \\
Hyun Lee, Abrar & & \\
Haider & &
\end{tabular}




\begin{tabular}{|c|c|c|}
\hline $\begin{array}{l}\text { Improving data } \\
\text { Quality in } \\
\text { Construction } \\
\text { Engineering } \\
\text { Project, Soffie } \\
\text { Westin }\end{array}$ & $\begin{array}{l}\text { Peningkatan } \\
\text { kualitas }\end{array}$ & $\begin{array}{lrr}\text { Membuat } & \text { framework } \\
\text { pengukuran } & \text { kualitas } \\
\text { informasi untuk } & \text { teknik } \\
\text { bangunan } & & \end{array}$ \\
\hline $\begin{array}{l}\text { Improvement of } \\
\text { Business Process in } \\
\text { order to Manage } \\
\text { the Quality of } \\
\text { Information, } \\
\text { Wendri }\end{array}$ & $\begin{array}{l}\text { Peningkatan } \\
\text { kualitas }\end{array}$ & $\begin{array}{l}\text { Model peningkatan kualitas } \\
\text { informasi melalui perbaikan } \\
\text { proses bisnis yang } \\
\text { disesuaikan dengan standar } \\
\text { proses hasil literatur }\end{array}$ \\
\hline $\begin{array}{l}\text { Applyinyg Six } \\
\text { Sigma Methodology } \\
\text { to Improve Quality } \\
\text { of Information: } \\
\text { Case of a } \\
\text { Manufacturing } \\
\text { Organisation, Sang } \\
\text { Hyun Lee, Abrar } \\
\text { Haider }\end{array}$ & $\begin{array}{l}\text { Framework } \\
\text { Peningkatan } \\
\text { kualitas }\end{array}$ & $\begin{array}{l}\text { Mencari hubungan dimensi } \\
\text { kualitas informasi, metode } \\
\text { yang digunakan dalam } \\
\text { mengimplementasikan six- } \\
\text { sigma adalah define, } \\
\text { Measure, analyze, improve } \\
\text { dan Control. }\end{array}$ \\
\hline $\begin{array}{l}\text { Information } \\
\text { Management in } \\
\text { UK-Based } \\
\text { Architecture and } \\
\text { Engineering } \\
\text { Organizations, } \\
\text { Abdullahi Sheriff } \\
\text { dkk }\end{array}$ & $\begin{array}{l}\text { Manajemen } \\
\text { informasi }\end{array}$ & $\begin{array}{l}\text { Membahas faktor-faktor } \\
\text { pendorong, constrain, dan } \\
\text { penghalang manajemen } \\
\text { kualitas informasi. }\end{array}$ \\
\hline $\begin{array}{l}\text { Designing Process } \\
\text { Maturity Measure } \\
\text { of Total Information } \\
\text { Management } \\
\text { (TIQM), I Gusti dan } \\
\text { Suhardi }\end{array}$ & $\begin{array}{l}\text { Kematangan } \\
\text { proses }\end{array}$ & $\begin{array}{lr}\text { Memodifikasi arsitektur } \\
\text { CMM, dengan proses } \\
\text { manajemen } & \text { kualitas } \\
\text { informasi diambil dari } \\
\text { TQIM. }\end{array}$ \\
\hline $\begin{array}{l}\text { Pengembangan } \\
\text { model kematangan } \\
\text { untuk pengelolaan, } \\
\text { Angelina }\end{array}$ & $\begin{array}{l}\text { Kematangan } \\
\text { proses }\end{array}$ & $\begin{array}{lr}\text { Model } & \text { kematangan } \\
\text { dikembangkan } & \text { untuk } \\
\text { meningkatkan proses siklus } \\
\text { hidup } & \text { informasi } \\
\text { (McGivray). } & \text { Atribut } \\
\text { kematangan } & \text { menggunakan } \\
\text { atribut kematangan COBIT } \\
\text { 4.1. }\end{array}$ \\
\hline Penelitian ini & $\begin{array}{l}\text { Framework } \\
\text { Peningkatan } \\
\text { kualitas } \\
\text { informasi }\end{array}$ & $\begin{array}{l}\text { Peningkatan } \\
\text { informasi } \\
\text { melakukan pengukuran } \\
\text { kualitas informasi melalui } \\
\text { proses produksi informasi } \\
\text { dan menggunakan tingkat } \\
\text { kematangan } \\
\text { produksi informasi sebagai } \\
\text { tolak ukur. }\end{array}$ \\
\hline
\end{tabular}

Penelitian serupa dengan penelitian ini sudah dilakukan oleh Wendri (2003) dengan peningkatan proses berdasarkan analisis gap proses bisnis saat ini dengan standar proses bisnis hasil literatur. Penelitian ini akan melengkapi penelitian sebelumnya dengan melakukan perbaikan proses bisnis dengan berdasarkan pada level kematangan proses menghasilkan informasi. Model Konseptual pada penelitian ini dapat dilihat pada Gambar 2.

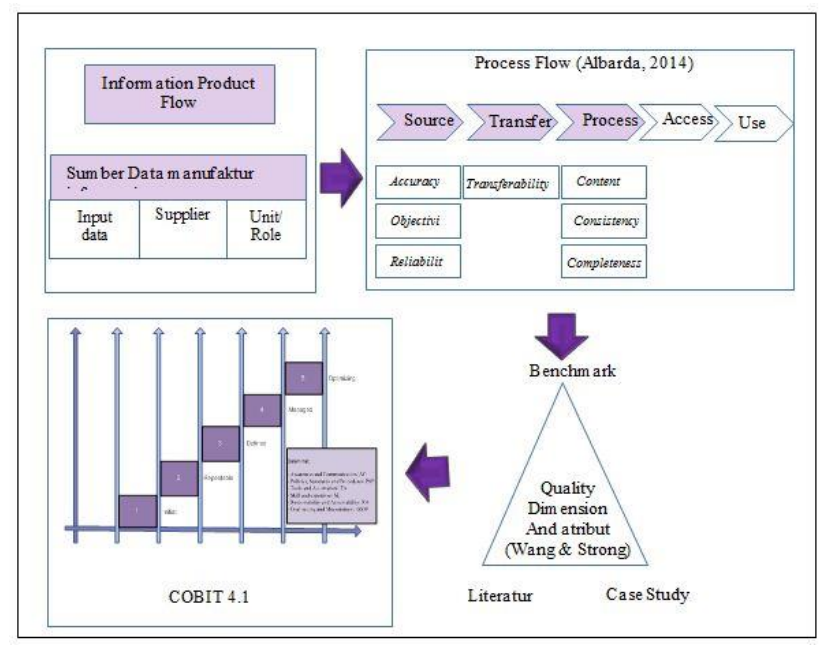

Gambar 2. Model konseptual penelitian

\section{PERANCANGAN FRAMEWORK}

Perancangan framework peningkatan kualitas informasi dalam penelitian ini akan menggunakan pendekatan Design Science Research Methodology yang terdiri dari: problem identification and motivation, define the objectives for solutions, design and development, demonstration, evaluation and communication.

Metodologi continuous improvement peningkatan kualitas informasi yang diadopsi adalah konsep continuous improvement TDQM yang terdiri dari Define-MeasureAnalyze-Improve. Model konseptual yang akan diterapkan dalam framework adalah seperti yang terlihat pada Gambar 2. Gambar tersebut secara garis besar mengilustrasikan bahwa dalam setiap tahap dalam aktivitas produksi informasi akan mempengaruhi dimensi kualitas informasi yang secara keseluruhan akan mempengaruhi kualitas informasi yang dihasilkan. Selain itu, Gambar tersebut menggambarkan bahwa untuk meningkatkan kualitas informasi yang dihasilkan dapat dilakukan dengan menjadikan tingkat kematangan proses sebagai tolak ukur dalam melakukan kontrol terhadap proses menghasilkan informasi. Framework yang dirancang dalam penelitian ini dapat dilihat pada Gambar 3.

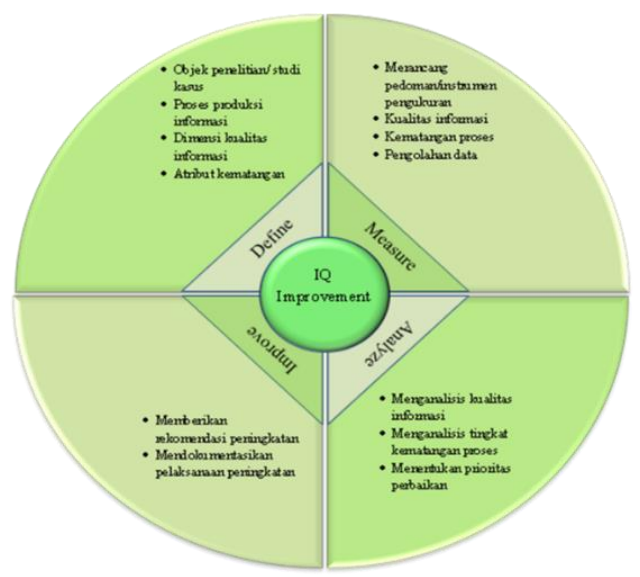

Gambar 3. Rancangan Framework Peningkatan Kualitas Informasi 


\section{A. Define}

Mendefinisikan spesifikasi dan posisi informasi yang dinilai sebagai informasi yang berkualitas, dengan tahapan: menentukan objek penelitian yang akan dilakukan penilaian, menganalisis proses produksi informasi, menentukan dimensi kualitas informasi, menentukan atribut kematangan.

\section{B. Measure}

Melakukan pengukuran terhadap kualitas informasi dan kematangan proses produksi, melalui tahapan: merancang pedoman/ instrumen yang diperlukan untuk pengukuran, mengumpulkan data dan fakta terkait kualitas informasi, mengumpulkan data dan fakta terkait dengan kematangan proses, melakukan pengolahan data yang diperoleh untuk mengetahui kualitas informasi dan tingkat kematangan.

\section{Analyze}

Dari hasil pengukuran, kemudian dilakukan analisis baik untuk kualitas informasi maupun untuk tingkat kematangan proses. Gambaran kualitas informasi dan tingkat kematangan dapat dilakukan analisis lebih lanjut untuk menentukan skala prioritas perbaikan yang dapat dilakukan. Tahap yang dilakukan adalah: menganalisis dimensi kualitas informasi yang kurang baik, menganalisis tingkat kematangan proses, menentukan prioritas perbaikan.

\section{Improve}

Berdasarkan hasil analisis kualitas informasi dan juga analisis tingkat kematangan proses dapat disusun rekomendasi untuk peningkatan kualitas informasi. Pada tahap ini juga dilakukan pendokumentasian pelaksanaan peningkatan. Pendokumentasian ini sangat penting untuk dilakukan, karena dapat dijadikan pengetahuan baru pada saat melakukan peningkatan kualitas pada masa yang akan datang.

\section{STUDI KASUS}

Untuk mendemonstrasikan rancangan framework yang diusulkan, dilakukan studi kasus untuk salah satu kegiatan yang dilakukan di BPS, yaitu kegiatan Survei Sosial Ekonomi Nasional (Susenas). Untuk dapat melakukan implementasi, diperlukan beberapa dokumen antara lain: dokumen pedoman pelaksanaan kegiatan Susenas, kuesioner kualitas informasi, dan kuesioner kematangan proses. Dokumen pedoman diperlukan untuk memperoleh gambaran proses yang dilakukan pada kegiatan Susenas. Kuesioner diperlukan sebagai instrumen pengumpulan data.

\section{A. Pengumpulan Data}

Sebelum survei dilakukan, kuesioner ditunjukkan kepada beberapa calon responden dan pakar kualitas informasi untuk menguji kualitas dan validitas kuesioner yang dihasilkan. Untuk tujuan tersebut, dipilih dua orang dari bagian yang bertanggung jawab dalam pelaksanaan kegiatan Susenas dan mengetahui gambaran kualitas informasi yang dihasilkan dan juga manajemen terkait kegiatan Susenas.

Berdasarkan perangkat survei yang telah disusun, survei dilakukan dengan membagikan kuesioner kepada sejumlah sampel, yaitu orang-orang yang berperan besar dalam kegiatan Susenas di BPS RI. Sampel dalam penelitian ini sejumlah 12 responden yaitu para eselon IV dan III di direktorat kesejahteraan rakyat, bagian yang bertanggung jawab terkait kegiatan Susenas. Direktorat kesejahteraan rakyat terdiri dari tiga sub direktorat, dan masing-masing subdirektorat terdiri dari 3 seksi.

Penyebaran kuesioner dilakukan pada tanggal 1 Desember 2015 dengan membagikan kuesioner kepada responden. Sebagian responden dapat ditemui secara langsung untuk menjelaskan maksud dan tujuan pengisian kuesioner. Untuk responden yang tidak dapat ditemui secara langsung, diberikan petunjuk singkat maksud dan tujuan penelitian.

\section{B. Analisis Hasil Survei}

Berdasarkan hasil survei yang dilakukan berkaitan dengan kualitas informasi dari kegiatan Susenas di peroleh hasil bahwa kualitas informasi yang dihasilkan sudah memuaskan, baik untuk dimensi Accuracy, Completeness maupun Timeliness. Ringkasan hasil pengukuran kualitas informasi seperti terlihat pada Tabel 2.

TABEl 2. HASIL PENILAIAN KuAlitas INFORMASI

\begin{tabular}{|l|l|c|c|c|c|}
\hline \multirow{2}{*}{$\begin{array}{c}\text { Dimensi } \\
\text { Kualitas }\end{array}$} & \multicolumn{1}{|c|}{ Atribut } & \multicolumn{2}{|c|}{ (As-Is) } & \multirow{2}{*}{ Total } \\
\cline { 3 - 5 } & & Sumber & Transfer & Proses & \\
\hline Accuracy & Accurate & 5,30 & & & \multirow{2}{*}{5,15} \\
\cline { 2 - 5 } Completeness & $\begin{array}{l}\text { Free of error } \\
\text { Complete }\end{array}$ & 5,00 & & & \multirow{2}{*}{$\begin{array}{l}\text { Include all } \\
\text { necessary } \\
\text { value }\end{array}$} \\
\cline { 2 - 5 } & $\begin{array}{l}\text { Up to date } \\
\text { Timeliness }\end{array}$ & 4,82 & 5,27 & \\
\cline { 2 - 5 } & $\begin{array}{l}\text { Delivered on } \\
\text { timely }\end{array}$ & 4,82 & & 5,00 & \multirow{2}{*}{5,04} \\
\hline
\end{tabular}

Secara umum kualitas informasi yang dihasilkan sudah memuaskan, dimensi completeness memiliki nilai yang terendah dibandingkan dengan kedua dimensi yang lain. Dari hasil pengukuran kualitas diperoleh hasil bahwa dimensi completeness berada pada tingkat kualitas yang memuaskan. Dimensi accuracy dan timeliness berada satu tingkat di atas dimensi completeness, yaitu sudah mencapai level sangat memuaskan.

Dalam penelitian ini juga dilakukan pengukuran tingkat kematangan proses produksi informasi. Berdasarkan survei yang dilakukan diperoleh gambaran tentang kondisi kematangan saat ini dan target berdasarkan modus dan rata-rata jawaban responden seperti terlihat pada Tabel 3. 
TABEL 3. RingKasAn HASIl SURVEI KeMATANGAN PER ATRIBUT

\begin{tabular}{|l|c|c|c|c|}
\hline \multirow{2}{*}{ Atribut } & \multicolumn{2}{c|}{ Modus } & \multicolumn{2}{c|}{ Rata-rata } \\
\cline { 2 - 5 } & Saat ini & Target & Saat ini & Target \\
\hline Kesadaran \& Komunikasi (AC) & 4 & 5 & 3 & 5 \\
\hline Kebijakan, Standar \& Prosedur (PSP) & 4 & 5 & 3 & 5 \\
\hline Perangkat \& Otomasi (TA) & 3 & 5 & 3 & 5 \\
\hline Keterampilan \& Keahlian (SE) & 4 & 5 & 3 & 4 \\
\hline $\begin{array}{l}\text { Tanggung Jawab \& Akuntabilitas } \\
\text { (RA) }\end{array}$ & 3 & 5 & 3 & 4 \\
\hline $\begin{array}{l}\text { Penetapan Tujuan \& Pengukuran } \\
\text { (GSM) }\end{array}$ & 4 & 5 & 4 & 5 \\
\hline Proses Produksi Informasi Susenas & $\mathbf{4}$ & $\mathbf{5}$ & $\mathbf{3}$ & $\mathbf{5}$ \\
\hline
\end{tabular}

Uraian hasil survei per atribut dari jawaban responden berdasarkan modus ditunjukkan pada Tabel 3. juga dapat digambarkan dalam bentuk diagram radar seperti pada Gambar 4. Atribut perangkat \& otomasi dan tanggung jawab \& akuntabilitas memiliki level kematangan yang lebih rendah dibanding dengan keempat atribut yang lain yaitu pada level 3 (defined). Sedangkan ke-empat atribut yang lain level kematangan saat ini mencapai level kematangan 4 (managed). Ke-enam atribut berdasarkan modus, ditargetkan mencapai level tertinggi yaitu level 5 (optimizing).
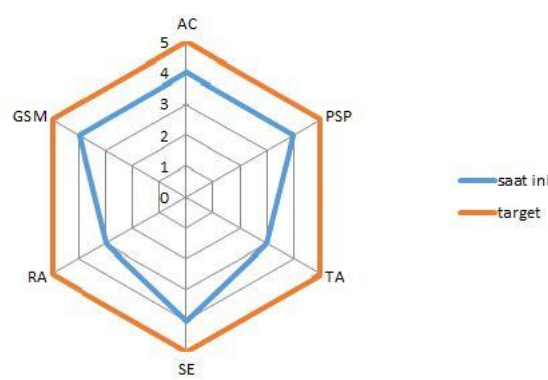

Gambar 4. Diagram radar level kematangan per atribut berdasarkan modus

Berdasarkan rata-rata jawaban responden, hasil penilaian kematangan per atribut juga dapat digambarkan dalam bentuk diagram radar seperti pada Gambar 5.

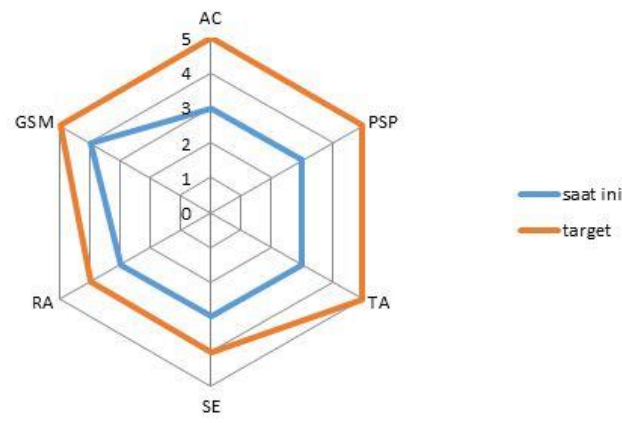

Gambar 5. Diagram radar level kematangan per atribut berdasarkan ratarata

\section{Strategi Peningkatan}

\section{Strategi Peningkatan Berdasarkan Kualitas Informasi}

Berdasarkan hasil pengukuran kualitas informasi dan dilakukan analisis lebih mendalam, dapat diperoleh beberapa solusi potensial untuk peningkatan kualitas informasi. Solusi potensial dianalisis untuk atribut dimensi kualitas informasi Beberapa solusi potensial terkait dengan kualitas informasi ditampilkan pada Tabel 4.

TABEL 4. Solusi Potensial PENINGKATAN BERDASARKAN ANALisis KUALITAS INFORMASI

\begin{tabular}{|c|c|}
\hline Kode & Solusi Potensial \\
\hline \multicolumn{2}{|c|}{$\begin{array}{l}\text { Include all necessary value } \\
\text { Completeness }\end{array}$} \\
\hline IQ1 & $\begin{array}{l}\text { Diperlukan form standar yang dapat digunakan oleh } \\
\text { pengawas untuk melakukan editing coding. Adanya blok } \\
\text { catatan juga dimanfaatkan untuk merekam informasi } \\
\text { tambahan dari pengawas, selanjutnya informasi tambahan } \\
\text { direkam ke dalam program entri untuk bahan tambahan } \\
\text { analisis. }\end{array}$ \\
\hline \multicolumn{2}{|c|}{$\begin{array}{l}\text { Up to date } \\
\text { Timeliness }\end{array}$} \\
\hline IQ2 & $\begin{array}{l}\text { Aplikasi yang digunakan untuk entri memfasilitasi adanya } \\
\text { perubahan range harga di daerah. Perubahan tersebut perlu } \\
\text { diatur dalam buku pedoman pengolahan. }\end{array}$ \\
\hline \multicolumn{2}{|c|}{$\begin{array}{l}\text { Delivered on timely } \\
\text { Timeliness }\end{array}$} \\
\hline IQ3 & $\begin{array}{l}\text { Perlu dibangun sistem informasi yang dapat digunakan } \\
\text { untuk melakukan pengawasan pelaksanaan kegiatan yang } \\
\text { terkait dengan proses produksi informasi. Perlu didukung } \\
\text { penetapan prosedur dan juga pihak yang bertanggung jawab } \\
\text { pada masing-masing tahap. Dengan adanya sistem } \\
\text { pengawasan juga akan mendukung komunikasi dan } \\
\text { meningkatkan kesadaran para pelaku. }\end{array}$ \\
\hline \multicolumn{2}{|c|}{$\begin{array}{l}\text { Free of error } \\
\text { Accuracy }\end{array}$} \\
\hline IQ4 & $\begin{array}{l}\text { Perlu dibangun sistem informasi yang dapat digunakan } \\
\text { untuk melakukan pengawasan pelaksanaan kegiatan yang } \\
\text { terkait dengan proses produksi informasi. Perlu didukung } \\
\text { penetapan prosedur dan juga pihak yang bertanggung jawab } \\
\text { pada masing-masing tahap. Dengan adanya sistem } \\
\text { pengawasan juga akan mendukung komunikasi dan } \\
\text { meningkatkan kesadaran para pelaku. }\end{array}$ \\
\hline \multicolumn{2}{|c|}{$\begin{array}{l}\text { Free of error } \\
\text { Accuracy }\end{array}$} \\
\hline IQ5 & $\begin{array}{l}\text { Aplikasi yang digunakan untuk entri memfasilitasi adanya } \\
\text { perubahan range harga di daerah. Perlu diatur dalam buku } \\
\text { pedoman pengolahan. }\end{array}$ \\
\hline
\end{tabular}

\section{Usulan Perbaikan Level kematangan}

Dari uraian hasil analisis level kematangan proses, dilakukan analisis lebih detail untuk mendapatkan usulan perbaikan mencapai level kematangan target. Untuk menentukan prioritas perbaikan, perlu lebih mengetahui gap per atribut berdasarkan rata-rata jawaban responden. Usulan perbaikan dibuat berdasarkan definisi dari masingmasing atribut pada level target. diusulkan perbaikan level kematangan sebagai berikut:

TABEL 5. SOlusi Potensial PENINGKATAN BERDASARKAN ANALISIS KEMATANGAN PROSES

\begin{tabular}{|l|l|l|}
\hline Kode & \multicolumn{1}{|c|}{ Atribut } & \multicolumn{1}{|c|}{ Usulan Perbaikan Kematangan } \\
\hline M1 & Perangkat \& & Pengintegrasian tools, penggunaan \\
& Otomasi (TA) & $\begin{array}{l}\text { tools pada area utama baik pada tahap } \\
\text { sumber, transfer, maupun proses. }\end{array}$ \\
& & $\begin{array}{l}\text { Pengintegrasian toolls dapat } \\
\text { dilakukan dengan penggunaan CAPI }\end{array}$ \\
& & (computer assisted personal \\
& & interviewing). Penggunaan CAPI \\
\hline
\end{tabular}




\begin{tabular}{|c|c|c|}
\hline & & $\begin{array}{l}\text { dapat meningkatkan Timeliness, } \\
\text { accuracy }\end{array}$ \\
\hline M2 & $\begin{array}{l}\text { Kebijakan, Standar } \\
\& \text { Prosedur (PSP) }\end{array}$ & $\begin{array}{l}\text { Adanya pengawasan untuk } \\
\text { memastikan bahwa prosedur yang } \\
\text { telah ditetapkan telah dilaksanakan. } \\
\text { Adanya sharing pelaksanaan kegiatan } \\
\text { untuk mendapatkan praktik terbaik } \\
\text { dari dalam organisasi. }\end{array}$ \\
\hline M3 & $\begin{array}{l}\text { Keterampilan \& } \\
\text { Keahlian (SE) }\end{array}$ & $\begin{array}{l}\text { Kebutuhan kompetensi untuk kegiatan } \\
\text { harus diperbarui, misalnya: Syarat } \\
\text { untuk menjadi pencacah harus } \\
\text { disesuaikan jika software sudah } \\
\text { menggunakan CAPI. Selain itu } \\
\text { pencacah perlu diberikan pelatihan } \\
\text { materi Susenas dan juga cara } \\
\text { penggunaan CAPI }\end{array}$ \\
\hline M4 & $\begin{array}{l}\text { Penetapan Tujuan } \\
\& \text { Pengukuran } \\
\text { (GSM) }\end{array}$ & $\begin{array}{l}\text { Pengintegrasian penetapan target pada } \\
\text { masing-masing tahap produksi } \\
\text { informasi. Misalnya dengan } \\
\text { dibangunnya sistem yang dapat } \\
\text { memonitor pencapaian target masing- } \\
\text { masing kegiatan (baik target capaian } \\
\text { maupun deadline waktu) }\end{array}$ \\
\hline M5 & $\begin{array}{l}\text { Tanggung Jawab } \\
\& \text { Akuntabilitas } \\
\text { (RA) }\end{array}$ & $\begin{array}{l}\text { Pendefinisian tanggung jawab Secara } \\
\text { jelas. Misalnya dengan RACI Cart. } \\
\text { Adanya budaya penghargaan bagi } \\
\text { pengemban peran yang berprestasi. }\end{array}$ \\
\hline M6 & $\begin{array}{l}\text { Kesadaran \& } \\
\text { Komunikasi (AC) }\end{array}$ & $\begin{array}{l}\text { BPS perlu memfasilitasi adanya } \\
\text { sosialisasi mengenai kebijakan dan } \\
\text { prosedur, perangkat dan otomasi, } \\
\text { keterampilan dan keahlian, tanggung } \\
\text { jawab dan akuntabilitas, serta } \\
\text { penetapan tujuan dan pengukuran } \\
\text { yang berkaitan dengan proses } \\
\text { produksi informasi Komunikasi } \\
\text { secara terstruktur dilakukan untuk } \\
\text { mencari solusi bersama atas } \\
\text { permasalahan yang timbul. }\end{array}$ \\
\hline
\end{tabular}

\section{Usulan Perbaikan}

Dengan memperhatikan solusi potensial dari strategi peningkatan berdasarkan analisis kualitas informasi dan juga usulan perbaikan untuk mencapai target level kematangan proses, maka dapat diusulkan rancangan perbaikan proses produksi informasi seperti terlihat pada Tabel 6. Prioritas perbaikan berdasarkan banyaknya komponen kualitas informasi dan kematangan yang berhubungan langsung dengan usulan perbaikan.

TABEL 6. ReKomendASI PERBAIKAN PROSES PRODUKSI INFORMASI

\begin{tabular}{|c|c|c|c|}
\hline No & Rekomendasi & $\begin{array}{l}\text { Kualitas } \\
\text { Informasi }\end{array}$ & $\begin{array}{l}\text { Kematangan } \\
\text { Proses }\end{array}$ \\
\hline 1. & $\begin{array}{l}\text { Perlu dibangun sistem informasi } \\
\text { yang dapat digunakan untuk } \\
\text { melakukan pengawasan } \\
\text { pelaksanaan kegiatan yang } \\
\text { terkait dengan proses produksi } \\
\text { informasi (pencacahan, editing } \\
\text { coding, entri, analisis, dsb). }\end{array}$ & IQ3, IQ4 & $\begin{array}{l}\text { M2,M6,M1, } \\
\text { M4, M5 }\end{array}$ \\
\hline 2. & $\begin{array}{l}\text { Menambahkan fasilitas update } \\
\text { range harga pada aplikasi data } \\
\text { entri. }\end{array}$ & IQ2, IQ5 & $\begin{array}{l}\text { M2, } \\
\text { M1 }\end{array}$ \\
\hline 3. & $\begin{array}{l}\text { Diperlukan form standar yang } \\
\text { dapat digunakan oleh pengawas } \\
\text { untuk melakukan editing coding. }\end{array}$ & IQI & $\begin{array}{l}\text { M1, M3, } \\
\text { M6 }\end{array}$ \\
\hline
\end{tabular}

\begin{tabular}{|c|c|c|c|}
\hline 4. & $\begin{array}{l}\text { Penggunaan CAPI (computer } \\
\text { assisted personal interviewing) } \\
\text { dalam pelaksanaan survei. }\end{array}$ & $\begin{array}{l}\text { IQ2, IQ3, } \\
\text { IQ4 }\end{array}$ & M1 \\
\hline 5. & $\begin{array}{lr}\text { Perlu adanya } & \text { sharing } \\
\text { pelaksanaan kegiatan } & \text { terkait } \\
\text { kegiatan sensus/ survei untuk } \\
\text { mendapatkan praktek } & \text { terbaik } \\
\text { internal dan eksternal. } & \end{array}$ & IQ3, IQ5 & M2, M6 \\
\hline 6. & $\begin{array}{l}\text { Pendefinisian tanggung jawab } \\
\text { secara jelas untuk semua pihak } \\
\text { yang terlibat, misalnya dengan } \\
\text { membuat RACI Cart, dan } \\
\text { Adanya budaya penghargaan } \\
\text { bagi pelaku kegiatan yang } \\
\text { berprestasi. }\end{array}$ & IQ3, IQ5 & M5 \\
\hline 7. & $\begin{array}{l}\text { Kebutuhan kompetensi para } \\
\text { pelaku kegiatan harus selalu } \\
\text { diperbarui dan disesuaikan } \\
\text { dengan kebijakan yang diambil. }\end{array}$ & IQ1 & M3 \\
\hline
\end{tabular}

Rancangan framework dan usulan perbaikan selanjutnya dilakukan validasi. Validasi dilakukan dengan melakukan wawancara dan diskusi dilakukan kepada Direktur Kesejahteraan Rakyat sebagai penanggung jawab kegiatan, dan juga kepada Kepala Sub direktorat yang menangani kegiatan. Langkah-langkah dalam framework yang dihasilkan dalam penelitian ini dinyatakan telah sesuai dengan prinsip-prinsip dan aturan yang tercantum dalam organisasi. Usulan perbaikan yang dihasilkan dapat digunakan sebagai acuan untuk pengelolaan kualitas informasi serta penyusunan road map rencana pengembangan aplikasi TIK di Direktorat Kesejahteraan Rakyat.

\section{KESIMPULAN}

Semua Informasi yang berkualitas tinggi telah menjadi kebutuhan yang sangat penting bagi negara untuk menjalankan roda pemerintahannya. BPS sebagai lembaga pemerintahan yang tugas utamanya adalah menyediakan data dan informasi yang berkualitas, selalu berusaha untuk meningkatkan kualitas informasi yang disajikan.

Beberapa hal yang dapat disimpulkan dari penelitian ini antara lain adalah: Framework dapat dijadikan panduan dalam rangka peningkatan kualitas informasi yang dihasilkan organisasi. Hasil studi kasus menunjukkan bahwa kualitas informasi sudah memuaskan, tetapi masih terlihat ada peluang untuk dapat meningkatkan kualitas informasi yang dihasilkan. Level kematangan proses produksi informasi kegiatan Susenas saat ini berapa pada level 3 (define) dan target yang ingin dicapai adalah level 5 (optimized), secara lebih detail juga dapat dilihat bahwa level kematangan berbeda untuk masing-masing atribut. Rancangan perbaikan yang diusulkan dapat diterima dan digunakan sebagai acuan untuk pengelolaan kualitas informasi kegiatan Susenas.

Untuk mengurangi kesalahan interpretasi dalam pengisian kuesioner, penelitian ke depan dapat dilakukan dengan cara wawancara atau adanya pendampingan pada saat pengisian kuesioner. Untuk penelitian lebih lanjut, perlu mengembangkan objek penelitian kualitas informasi tidak terbatas pada Information Production namun juga dapat diperluas sampai pada Information Delivery. 


\section{DAFTAR PUSTAKA}

[1] Abdullahi Sheriff dkk., "Information Management in UKBased Architecture and Engineering Organizations : Drivers, Constraining Factors, and Barriers," Journal of Management in Engineering, ASCE Vol. 28, No. 2, April 1, 2012.

[2] Albarda, , "Classification of Information Use (IU) on the Information Resource Services," International Conference on Telecommunication Systems, Services, and Aplications, IEEE, 2012.

[3] Angelina Prima Kurniati, "Pengembangan Model Kematangan untuk Pengelolaan Kualitas Informasi," Proceedings of Informing Sience \& IT Education Conference (InSITE), 2010.

[4] Ardani Yustriana Dewi, "Assessing Information Quality Management Maturity Level Using TIQM-CMM," International Conference on Information Technology Systems and Innovation (ICITSI), 2014.

[5] Asadullah Shaikh dkk, "Strengths and Weaknesses of Maturity Driven Process Improvement Effort," International Conference on Complex, Intelligent and Software Intensive Systems, IEEE, 2009.

[6] Ge, M., Helfert, M., "A Review of Information Quality Research - Develop A Research Agenda", 2007.

[7] Ge, M. (2009) : Information Quality Assessment and Effects on Inventory Decision-Making, Disertasi Program Doktor, School of Computing.

[8] I Gusti Rama Gunawan and Suhardi, "Designing Process Maturity Measure of Total Information Management (TIQM)," 2nd International Conference on Business and Information Management (ICBIM), 2014.

[9] I Payam Shariat Panahy, dkk., "The Impact of Data Quality Dimensions on Business Process Improvement," Information and Communication Technology (WICT), IEEE, 2014

[10] Lee, Sang Hyun and Heider, Abrar, "Applying Six Sigma Methodology to Improve Quality of Information:Case of a Manufacturing Organisation," Proceedings of PICMET'12: Technology Management for Emerging Technologies, 2012.

[11] Lee, Sang Hyun and Heider, Abrar, "Identifying Relationships of Information Quality Dimensions," Proceedings of PICMET'13: Technology Management for Emerging Technologies, 2013.

[12] Madnick, Stuart E., Wang, Richard Y., Lee, Yang W., Zhu, Hongwei, "Overview ad Framework for Data and Information Quality Research," ACM journal of Data and Information Quality, 2009.

[13] Matthias Goeken and Stefanie Alter, "Toward Conceptual Metamodeling of IT Governance Frameworks ApproachUse-Benefits," Proceedings of the 42nd Hawaii International Conference on System Sciences, 2009.

[14] Naumann, F., \& rolker, C, "Assessment Methods for Information Quality criteris," Proceeding of the 2000 Conference on Information Quality, 2000.

[15] Richard M. Adler, "A Dynamic Capability Maturity Model for Improving Cyber Security,” IEEE, 2013.

[16] Soffi Westin and Maung K. Sein, "Improving Data Quality in Construction Engineering Project: An Action Design Research Approach," Journal of Management in Engineering, ASCE, April 26, 2013.

[17] Strong, D.M., Lee, Y. W., dan Wang, R. Y., "Data Quality on Context," Communication of the ACM, vol. 40, no. 5, h. 103110, 1997.
[18] Stvilia, B., Gasser, L., Twidale, M. B., dan Smith L. C., "A Framework for Information Quality Assessment," Journal of the American Society for Information Science and Technology, Wiley Inter Science, h. 1720-1733, 2007.

[19] Wang, R.Y. dan Strong, D.M., "Beyond Acuracy: What Data Quality Means to Data Consumers," Journal of Information Systems, 1996.

[20] Wendri Syahreza Nasution and Albarda, "Improvement of Business Process in order to Manage the Quality of Information," International conference on ICT for smart Society (ICISS), 2013. 